\title{
Protecting the Environment and People from Climate Change through Climate Change Litigation
}

\author{
Theodore Okonkwo ${ }^{1}$ \\ ${ }^{1}$ Department of Public Law, Faculty of Law, University of Port-Harcourt, Port-Harcourt, Nigeria \\ Correspondence: Theodore Okonkwo, Department of Public Law, Faculty of Law, University of Port-Harcourt, \\ Port-Harcourt, Nigeria. E-mail: t161962@gmail.com; theodore.okonkwo@uniport.edu.ng
}

Received: July 14, 2017

doi:10.5539/jpl.v10n5p66
Accepted: September 4, 2017

Online Published: November 29, 2017

URL: https://doi.org/10.5539/jpl.v10n5p66

\begin{abstract}
Climate change litigation seeks to apply legal rights in order to affect the outcomes that would either mitigate, reduce or can even result in improved alternation to climate change. This article intends to identify and analyse the ways through which the environment and the people are protected from rapid changes in climate through the means of climate change litigation. Protection of the environment as well as people by climate change litigation can be witnessed in various nations throughout the globe particularly Australia, the US, Canada and the UK. The research problem examined in this article shows that the courts are becoming a critical climate change front where climate change conflicts are resolved. The research objectives are to help understand how climate change has impacted human health and the environment and how the courts have stepped into the arena to restrain activities that cause climate change impact. The methodology adopted in this article is both doctrinal and theoretical drawing upon primary and secondary sources of information. The key findings and implications to theory and practice of this article is that it is a medium to foster the jurisprudence of the role of climate change regime through judicial intervention in protecting the environment and people from climate change through climate change litigation.
\end{abstract}

Keywords: climate change, litigation, people, environment, protection, lawsuits, mechanism, legal cases

\section{Introduction}

In the recent years, change in climate has become a common phenomenon, which is believed to occur due to alterations in the pattern of long-term weather such as through human activity. ${ }^{1}$ Changes in climate are principally measured on the basis of the rate of global warming. ${ }^{2}$ In the last 650,000 years, several glacial cycles retreated and advanced marking the commencement of the contemporary era as well as of the human civilization. ${ }^{3}$ Majority of the climate changes are particularly attributed to small alternations in the orbit of the earth. ${ }^{4}$ There are several evidence for the rapid change in climate, such as rise in the level of sea, global temperature, warming oceans, shrink of ice sheets to name to few. ${ }^{5}$ Over the past few years, laws regarding changes in climate have grown to a large extent. ${ }^{6}$ Litigation has also increased across the world, ${ }^{7}$ which is observed as a mechanism to compel the industries and government to effectively respond to the climate change threats. ${ }^{8}$ The term, "climate change litigation' in this case refers to the legal cases in which the central focus is to obtain protection from climate change impacts, ${ }^{9}$ "or to sue a company for causing climate-related harm". ${ }^{10}$ According to Vanhala and Hilson,

\footnotetext{
1 The David Suzuki Foundation, 'What is climate change?' (Issues, 2014) $<$ http://www.davidsuzuki.org/issues/climate-change/science/climate-change-basics/climate-change-101-1/> accessed July 7th 2017

The David Suzuki Foundation, 'What is climate change?' ibid.

The David Suzuki Foundation, 'What is climate change?' ibid.

The David Suzuki Foundation, 'What is climate change?' ibid.

Holly Shaftel, 'Climate Change: How Do We Know?' (Facts, 26 June 2017) <https://climate.nasa.gov/evidence/> assessed July 7th 2017.

Meredith Wilensky, 'Climate Change In The Courts: An Assessment Of Non-U.S. Climate Litigation' (2015), 1-52.

Risteard de Paor, 'Climate Change and Arbitration: Annex Time Before There Won't Be A Next Time' (2017). Journal of International Dispute Settlement, Vol. 8 (1): 179 - 215. DOI: https://doi.org/10.1093/jnlids/idw025.

Rachel Pepper, 'Climate Change Litigation: A Comparison Between Current Australian and International Jurisprudence' (2012), 1-16. Rachel Pepper, ibid.
} 
"individuals, communities and even whole nations are increasingly exploring these possibilities, broadly termed 'climate change litigation'. Thus, climate change litigation particularly seeks to apply legal rights in order to affect the outcomes that would either mitigate, reduce or can even result in improved alteration to climate change. ${ }^{11}$ However, litigation has not been considered as an important mechanism to push the market participants and the policymakers to create as well as implement an effective way of adaptation and mitigation of the climate change than in present years. ${ }^{12}$

According to a study by the United Nations Environment and Columbia Law School, ${ }^{13}$ there is an increase in the "proliferation" of law suits filed by citizens and environmental groups seeking redress against climate impact activities, such "as sea-level rise, coal-fired power plants and oil drilling". Erik Solheim ${ }^{14}$ has stated that:

It's patently clear we need more concrete action on climate change, including addressing the root causes and helping communities adapt to the consequences... The science can stand up in a court of law, and governments need to make sure their responses to the problem do too.

This article argues that national governments and corporations globally are "increasingly" being dragged to court "to do more to combat the threat of climate change". ${ }^{15}$ Despite this development, most of these law suits are unsuccessful. According to Michael Burger:

We haven't seen any major wins filed in actions against fossil fuel companies but there have been successes in lawsuits against governments. A lot of this legal action is in the US because America is a litigious society but also because there is such a partisan divide over the fundamental reality of climate change, which doesn't really exist elsewhere in the world. ${ }^{16,17}$

Burger argues that lawsuit is a potent tool to compel national governments to implement "their agreed target of avoiding global warming of $2^{\circ} \mathrm{C}$ or more compared to the era shortly before the advent of heavy industry". Burger argues that:

The role of litigation will be different in each country but will continue to see an increase in climate lawsuits that make explicit reference to the Paris agreement. In the US, I do not think that any court will hold the government to account over Paris as it's not binding, but other courts in other countries may give it different weight. Legal action will be used to stave off the worst aspects of climate change. Litigation has been absolutely essential in instigating action in the US and elsewhere, and it will continue to be so. ${ }^{18}$

The reasons for litigations vary from nation to nation but the common idea based on which such lawsuits are implemented is to drive the changes in policy that particularly lacks international and national actions to mitigate issues of climate change. Based on the above presented notion, this article highlights the ways in which the environment as well as the people are protected from the rapid change in climate through the means of climate change litigation.

\section{Overview of the Climate Change Litigation Mechanism}

Climate change litigation is referred to as the legal actions usually taken by the applicants, in which they seek the court's intervention for enforcing or clarifying the integration of existing law to the issues of the climate change. Litigation, in terms of climate change, can be explained as a process in which the applicants seek to obtain legal outcomes from the court either to redress the harm caused by climate change impact or to support the actions of climate in some manner. In this context, generally the applicants are regarded as the citizens or groups who seek redress from government or companies that fail to comply with their legal obligations to reduce greenhouse gas emissions. However, in some cases, a separate type of climate litigation involves seeking actions against the

\footnotetext{
10 Lisa Vanhala and Chris Hilson, 'Climate Change Litigation - A Rising Tide?'(2012), Roundtable on Climate Change Litigation Policy and Mobilisation, (London) http://cdkn.org (accessed July 8, 2017).

11 Rachel Pepper, ibid.

12 UN Environment Programme, 'The Status Of Climate Change: A Global Review' (2017), 1-41.

13 United Nations Environment Programme, The Status of Climate Change Litigation - A Global Review (2017). UNON Publishing Services Section, Nairobi, Kenya), $4-41$.

14 Head of UN Environment.

15 Oliver Milman, 'More People Heading to Court to Spur action on Climate Change, Study Finds' (2017). The Guardian available at https:/www.theguardian.com/environment/2017/may/23/climate_change_government_court_cases_study (accessed July 9, 2017).

16 Executive director of the Sabin Centre for Climate Change Law at Columbia, ibid.

17 Cited in Oliver Milman, ibid.

18 Oliver Milman, ibid.
} 
government to challenge the authority of laws approved to deal with climate changes. ${ }^{19}$ Since 2014, the amount of lawsuits, particularly including climate change has increased, from which majority of the cases are filed usually by the non-governmental organizations or by the individuals themselves. ${ }^{20,21}$ Nearly 177 countries have been familiar with the individuals' rights to a healthy environment, owing to which the courts are facing pressure to emphasize the implications for the rights related to climate change. ${ }^{22}$ Nonetheless, the technology cannot be sufficed in addressing the forthcoming issues, for which the policies and laws are required to be the essential part of each strategy. ${ }^{23}$ This is acknowledged with the Paris Agreement, which is done in order to control the severe changes in climate. ${ }^{24}$ The climate litigation is dwarfing other types of litigations in terms of the number of applicants as well as the timeframe. In recent years, the climate litigation is growing at an alarming rate and even exceeding the asbestos and tobacco litigations. ${ }^{25}$ This is principally because the governments are continuously failing in consideration to actions to mitigate the issues. The tobacco litigations were effective because the government took initiatives that resulted in lasting solutions. The applicants argued that the tobacco industry is responsible for affecting public health. ${ }^{26}$ The most common industry responsible for climate change is the fossil fuel corporations, accounting nearly $70 \%$ of emissions in greenhouse gas. ${ }^{27}$ This industry is not only accountable for creating such massive amount of emissions but also is responsible for delaying in addressing the issue. ${ }^{28}$ The international law is correspondingly in view that the industry must compensate for the damages and losses against the harm caused by their products. ${ }^{29}$

The non-governmental agencies and citizens are litigating to hold the respective government accountable for their commitments regarding the climate. ${ }^{30}$ However, in recent years, technical understanding regarding the changes in climate as well as the quality of forecasting regarding the future temperature and the extent to which the climate is likely to be changed has been improving. ${ }^{31}$ However, litigants are presenting claims looking for assignment of responsibilities, wherein failures to become accustomed with most of the effects is foreseeable. Majority of the litigants have thus been arguing for climate actions, relying upon the doctrine of public trust that particularly dispense the responsibility of the state to maintain integrity of the public trust, particularly for the future generations. ${ }^{32}$ However, the climate change litigations at present are mostly prevalent in the developed countries, such as New Zealand, Australia, United Kingdom, United States, Netherlands and Austria. ${ }^{33}$

\subsection{Protection of Environment and People by Climate Change Litigation in Australia}

Australia has over 80 cases dealing with climate litigation. ${ }^{34}$ Australia's legal systems are based on common law and have inherited its framework of law from the UK. ${ }^{35}$ In Australia, there are several obstructions in generating successful climate change litigation outcomes, such as in both tort and consumer laws. ${ }^{36}$ For instance, according to the consumer law, when a corporation or an individual are sued for misleading or false environmental claims, reimbursement is awarded only to the consumers, without considering any kind of remedial benefit for the environment. ${ }^{37}$ The climate change litigation was initiated in Australia in 1994 in which questions were raised regarding lack of requirement to integrate new power station, as this would result in increased $\mathrm{Co}_{2}$ emissions

9 Keely Boom and others, 'Climate Justice: The International Momentum Towards Climate Litigation' (2016), 1-72.

20 Phys.org, 'Climate Change Litigation Growing Rapidly, Says Global Study' (Environment, 25 May 2017) $<$ https://phys.org/news/2017-05-climate-litigation-rapidly-global.html > assessed July 7th 2017.

21 Chris Hilson, 'Climate Change Litigation in the UK: An Explanatory Approach (or Bridging Grievance Back In)' (2011), 1-18.

22 Chris Hilson, 'Climate Change Litigation in the UK: An Explanatory Approach (or Bridging Grievance Back In)', ibid.

23 Chris Hilson, 'Climate Change Litigation in the UK: An Explanatory Approach (or Bridging Grievance Back In)', ibid.

24 Chris Hilson, 'Climate Change Litigation in the UK: An Explanatory Approach (or Bridging Grievance Back In)', ibid.

25 Keely Boom, 'Climate Justice: International Momentum Towards Litigation' (Home, 30th May 2017) $<$ http://climatejustice.org.au/climate-justice-international-momentum-towards-litigation/ > assessed 7th July 2017

Keely Boom, 'Climate Justice: International Momentum Towards Litigation', ibid.

Keely Boom, ‘Climate Justice: International Momentum Towards Litigation', ibid.

Keely Boom, 'Climate Justice: International Momentum Towards Litigation', ibid.

Keely Boom, 'Climate Justice: International Momentum Towards Litigation', ibid.

UN Environment Programme, 'The Status Of Climate Change: A Global Review' (2017), 1-41.

UN Environment Programme, 'The Status Of Climate Change: A Global Review', ibid.

UN Environment Programme, 'The Status Of Climate Change: A Global Review', ibid.

UN Environment Programme, 'The Status Of Climate Change: A Global Review', ibid.

See Oliver Milman, ibid.

Rachel Pepper, 'Climate Change Litigation: A Comparison between Current Australian and International Jurisprudence' (2012), 1-16.

Rachel Pepper, ibid.

Rachel Pepper, ibid. 
opposing the international and Australian policies. In Greenpeace Australia v Redbank Power Company, ${ }^{38}$ the court had dismissed the Act stating that legislation did not limit the development of new power stations. Besides, there are several other litigations for climate change recorded in the recent years such as Walker v Minister for Planning. ${ }^{39}$ In this litigation, the claimant argued that the Minister had deliberately failed to consider ecologically sustainable development (ESD) while approving the development proposal of homes in flood-prone area. This case has essential implications that direct the Minister to protect the interests of the people as well as the environment. ${ }^{40}$ Illustratively, Australia has been observed to have worst records of environment among the other developed nations. ${ }^{41}$ The Nathan Dam case is one such example, which had both direct and indirect impacts on the species. ${ }^{42}$ The court held that the minister was responsible for considering all the adverse effects, for which the minister was ordered to pay legal costs to the Queensland Conservation Council and WWF (see Figure 1). ${ }^{43}$

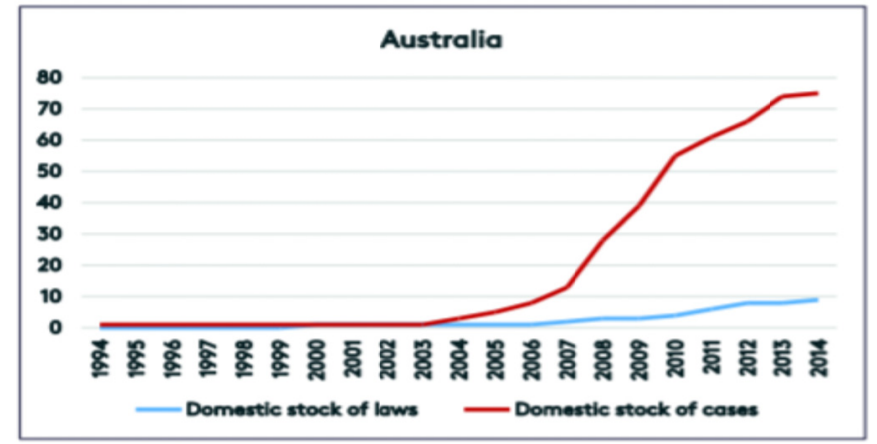

Figure 1. Growth of legal cases regarding climate change litigation ${ }^{44}$

The above presented graph indicates the growth of the legal cases recorded in Australia, since 1994, both in terms of domestic laws and cases. In Australia, there have been several cases undertaken by the Australian courts, ${ }^{45}$ particularly addressing the impacts of global warming related to the proposed developments. ${ }^{46}$

\subsection{Protection of Environment and People by Climate Change Litigation in the US}

A greater number of climate change litigation is found in the United States as statistics shows over 654 "climate-related cases" that is, about two-thirds of climate change litigation arising globally.

Recently in the US, several measures have been taken to protect the environment as well as the people from the climate change, particularly from the fossil fuel corporations. ${ }^{47}$ It is hence supposed that when these fossil fuels are burned, greenhouse gases are emitted, thereby warming atmosphere that further deteriorates the environment. The landmark recent litigation of Juliana $v$. United States ${ }^{48}$ can be referred to as one of the examples in which climate change issues were raised. In this case, the plaintiffs made up of 21 young children across the US sought

\footnotetext{
38 [1994] NSWLEC 178 (10 November, 1994).

39 [2007] NSWLEC 741. This decision has been amended.

40 EDO NSW, 'Walker v Minister for Planning' (Cases, 29 November 2007) $<$ http://www.edonsw.org.au/walker $>$ assessed 7th July 2017

41 Tracy Bach and Justin Brown, 'Recent Developments in Australian Climate Change Litigation: Forward Momentum From Down Under' (2008) 8, 1-9.

42 Queensland Conservation Council Inc. \& WWF Australia v. Minister for the Environment and Heritage [2003] FCA 1463; Minister for the Environment and Heritage v. Queensland Conservation Council Inc. \& WWF Australia [2004] FCAFC 190.

43 Ibid.

44 Michal Nachmany et al, 'Global Trends in Climate Change Legislation and Litigation' (2017), 1-27.

45 Peel, Jacqueline, 'Climate Change Law: The Emergence of a New Legal Discipline' (2008) MelbULawRw 29; (2008) 32 (3) Malbourne University Law Review 922.

46 Thornton v. Adelaide Hill Council [2006] 151 LGERA 1. Where an Australian state court upheld a council decision to grant provisional Development Plan consent to a shed that would house a four megawatt capacity coal-fired boiler. Local landowners challenged the council's decision, asserting that the boiler will have detrimental impacts on the local environment by among other grounds, releasing greenhouse gases. The court found no evidence in this case of a likely increase in greenhouse gas emissions by the proposed development compared with the existing operation. The court nevertheless, accepted the fact that increasing greenhouse gas emissions may be inconsistent with the principles of ecological sustainable development, including the principles of intergenerational equity and the precautionary principle.

47 Rachel Pepper, 'Climate Change Litigation: A Comparison between Current Australian and International Jurisprudence' (2012), 1-16.

48 Case No. 6: 15 - cv-01517-TC (Opinion and Order) Filed 11/10/16. Judge Coffin's Order can be read in its entirety at http://ourchildrentrust.org/sites/default/files/16.04/08. Order Denying MTD.pdf (accessed July 9, 2017).
} 
for declaratory relief against the defendants, stating that they have been breaching the constitutional rights of the applicants to property, life and liberty as well. ${ }^{49}$ The defendants included the former US President, Barack Obama and other executive agencies. The applicants alleged that these defendants permitted Co 2 concentration that has been rising to levels unparalleled within human history. ${ }^{50}$ On appeal the Federal court affirmed the constitutional rights of the 21 kids. Besides, recently the US has also criticised India's authority regarding the law enforcements concerning solar energy based on the requirement in their domestic content through the World Trade Organization. ${ }^{51}$

In the case of American Electric Power Co v Connecticut, ${ }^{52}$ the plaintiffs sought an order from the court against the company to reduce the emissions generated from its activities. The case was dismissed on the ground that the act concerned with the clean air displaces the federal law communal nuisance arguments. ${ }^{53}$ In the US, litigation related to climate change is considered absolutely essential, beginning from the first proceedings challenging the US Environmental Protection Agency to effectively regulating the emissions of greenhouse gas. ${ }^{54}$ This has continued to the present proceedings that claims legitimate right for a steady climate system. ${ }^{55}$ Nonetheless, not only in the US but also in other countries, excessive reliance on technology and other policies are insufficient to deal with the prevailing threats associated with climate change. ${ }^{56}$

Recently some U.S. airlines filed law suit against the European Union contesting the later's move to extend its Emissions Trading Scheme (ETS), ${ }^{57}$ thus, making airlines flying into EU airports subject to a cap on their emissions and are required to buy carbon credits in order to be entitled to pollute. The European Union won the case. $^{58}$

In 2011, some plaintiffs from the United States biofuel industry filed law suit against the state of California challenging its low carbon fuel policy. ${ }^{59}$ In 2007 in the case of Massachusetts, et al v. Environmental Protection Agency, et al, ${ }^{60}$ where, based on respected scientific opinion that a well-documented rise in global temperatures and attendant climatological and environmental changes have resulted from a significant increase in the atmospheric concentration of "greenhouse gases", a group of private organizations, various states and cities filed lawsuit against Environmental Protection Agency (EPA) demanding that it regulates carbon dioxide and other greenhouse gas emissions. The court held that the petitioners have standing to challenge the EPA's denial of their rule making petition, that "the harms associated with climate change are serious and well recognized. The Supreme Court decided against EPA, thus, forcing EPA into determining by its rule making that greenhouse gases are a public health threat. This was the case that opened the way for former president Barack Obama's Executive Order on climate change.

\subsection{Protection of Environment and People by Climate Change Litigation in the United Kingdom (U.K.)}

In the UK, the corporations have brought several cases to address the climate change issue. ${ }^{61}$ The UK based industry actors have further brought about these cases to the court to challenge the policies and rules that

\footnotetext{
49 Ibid.

$50 \quad$ Sean Merritt, 'No Ordinary Lawsuit: Juliana v. United States is a Landmark Precedent for Climate Change Legislation' (Academic Commentary, 6th January 2017) <http://www.jurist.org/forum/2017/01/Gabriela-Steier-juliana-v-united-states.php > assessed 7th July 2017

51 Keely Boom, et al, 'Climate Justice: The International Momentum towards Climate Litigation' (2016), 1-72.

131 S.ct. 2527 (2011).

Keely Boom, et al, 'Climate Justice: The International Momentum towards Climate Litigation' (2016), 1-72.

United Nations Environment, 'New Study Identifies Key Trends In Worldwide Climate Change Litigation' (Environmental Governance, $\quad 23 \quad$ May 2017) $<$ http://www.unep.org/environmentalgovernance/new-study-identifies-key-trends-worldwide-climate-change-litigation $>$ assessed 8th July 2017

55 United Nations Environment, 'New Study Identifies Key Trends In Worldwide Climate Change Litigation', ibid.

56 United Nations Environment, 'New Study Identifies Key Trends In Worldwide Climate Change Litigation', ibid.

57 Katherine B. Andrus, 'Beyond Aircraft Emissions: The European Court of Justice's Decision May Have Far-Reaching Implications' (2012). The Air and Space Lawyer Volume 24, No. 4, 1 - 8.

58 Byrd v. Comair, Inc. (In re Air Crash at Lexington, ky.) 501F. supp. 2d 902, 907 (E.D., Ky. 2007) (citing Ehrliah v. Am. Airlines Inc., 360 F.3d 366, 371

59 Rocky Mountain Farmers Union, Redwood County Minnesota Corn and Soybean Growers, Penny Newman Grain Inc., Growth Energy, Renewable Fuels Association, Rex Nederend, Fresno County Farm Bureau, Nisei Farmers League and California Dairy Campaign. V. James N. Goldstone, Executive Officer of the California Air Resources Board case 1: 09 - cv - 02234- CJO-GSA. Document 259, filed $12 / 29 / 11$ page 2 of 38 .

60549 U.S. 497 (2007). Argued November 29, 2006, decided April 2, 2007.

61 Lisa Vanhala, 'The Comparative Politics Of Courts And Climate Change' (2013), 447-474.
} 
particularly affect the interests of the business at large ${ }^{62}$ Besides, the NGOs are also the claimants that bring cases to the court seeking to reduce the emissions of GHG or with the aim to promote policies related to the renewable energy. ${ }^{63}$ The UK has in this regard taken several proactive measures to protect the people and the environment from the climate change with the help of relevant litigations in this regard. ${ }^{64}$ Its approach has been ambitious while the country conducts far-reaching agendas regarding the climate change throughout the world. ${ }^{65}$ Over the past few years, the government of the UK have passed several laws to regulate the GHGs as well as develop other legal provisions. ${ }^{66}$ These legal provisions were applicable on the renewable energy, bio fuels, energy efficiency and other measures to encourage investments particularly to integrate low-carbon equipment and technologies. ${ }^{67}$ In the UK, the existence of wind farms particularly dominated the early cases of the climate change. ${ }^{68}$ There are several high profile cases in the UK as well, which have created a meaningful base to protect the environment and people from the climate change. ${ }^{69}$ For instance, in the case of Kingsnorth $\mathrm{Six}^{70}$ in 2008, the UK court set free the six climate change protesters causing damage in a coal power plant. ${ }^{71}$ The six protesters made attempts to shut down the plant and argued that this particular activity would lead to the prevention of damage for a day to the climate. Since then, there have been several other protests to protect the environment and the people at large. ${ }^{72,73}$

\subsection{Protection of Environment and People by Climate Change Litigation in Canada}

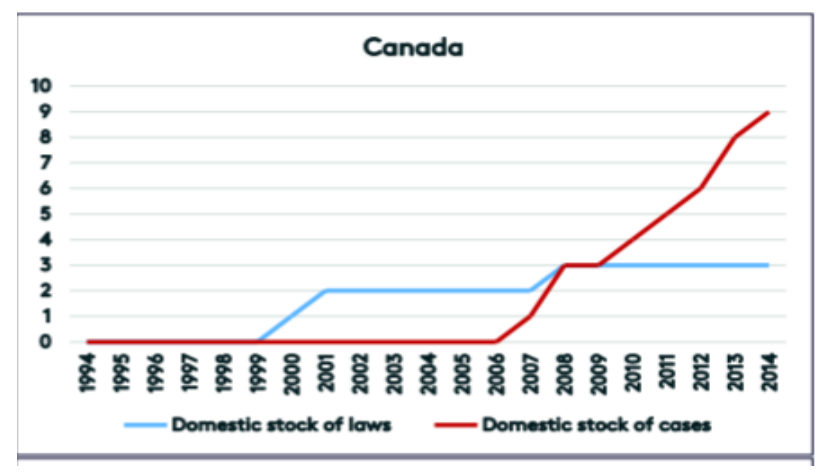

Figure 2. Canada's legal cases growth regarding climate change litigation ${ }^{74}$

Though Canada has ratified the Paris Agreement, it does not have a comprehensive legislation regarding climate change. However, it has several national legislations which "either in whole or in part" could be used to further

\footnotetext{
62 The U.K. has over 49 cases on climate litigation.

63 Chris Hilson, 'Climate Change Litigation in the U.K.: An Explanatory Approach (or Bringing Grievance Back In)' (2010). https://www.reading.ac.uk.web/files/law (accessed July 9, 2017).

64 Chris Hilson, 'Climate Change Litigation in the U.K.: An Explanatory Approach (or Bringing Grievance Back In)' (2010). https://www.reading.ac.uk.web/files/law (accessed July 9, 2017).

65 Hari Osofsky, 'Adjudicating Climate Change Across Scales'. Adjudicating Climate Change: State, National, and International Approaches' (2009). 373 - 385.

66 Graene Hayes, 'Negotiating Proximity: Expert Testimony and Collective Memory in the Trials of Environmental Activists in France and the United Kingdom', (2013). Law and Policy Vol. 35, Issue 3. Pp. 208 - 235. Doi 10.111/lapo-12004.

67 See, Department for Environment, Food and Rural Affairs, and Department of Energy and Climate Change (2015). Policy Paper, 2010 - 2015 Government Policy: Greenhouse Gas Emissions. https://www.gov.uk (accessed July 9, 2017).

68 Jacqueline Peel and Hari M. Osofsky, 'Climate Change Litigation: Law and Legislation' (2015). Cambridge University Press.

69 Chris Hilson, ibid.

70 Six Greenpeace climate change (activists) protesters were cleared of causing $£ 30,000$ of criminal damage at a coal-fired power station. The protesters at their trial argued that their action of trying to shut down the station by occupying the smokestack and painting the word "Gordon" down the chimney, was legally justified because they were trying to prevent climate change causing greater damage to property around the world..

71 See, David Abam, 'Climate Change in Court' (2011). Nature Climate Change 2, 127 - 130. Doi:10.1038/nclimate1131.

72 Ibid.

73 Desmog Canada, 'Climate Litigation is Here and it Could Cost Canadian Oil Companies Billions' (Home 9th October 2014) $<$ https://www.desmog.ca/2014/10/09/climate-litigation-here-and-it-could-cost-canadian-oil-companies-billions $>$ assessed 8 th July 2017.

74 Michal Nachmany, et al, 'Global Trends in Climate Change Legislation and Litigation' (2017), 1-27.
} 
climate impact action at the national level. ${ }^{75}$ Canada is still in its infancy in climate change litigation compared with the United States, Australia, United Kingdom and Netherlands. This article however, argues that Canada has a great future in climate change litigation. This is so because the government has placed climate change on its national priority list. This is buttressed by the number of legislations pertaining wholly or partly to this emerging area of our legal jurisprudence (see Figure 2 above).

Two cases illustrate the willingness of the Canadian courts to embrace climate change litigation. ${ }^{76}$ In the case of Voters Taking Action on Climate Change v. British Columbia (Energy and Mines),${ }^{77}$ the petitioner, Voters Taking Action on Climate Change (VTACC) sought the court's intervention to review decisions which proposed to expand the Texanda Quarrying Ltd's (TQL's) coal handling and storage operation on Texanda island ${ }^{78}$ on climate change issues. The Supreme Court of Canada held that VTACC does not have public interest standing to challenge the decisions which it held "did not engage the public interest or the larger issue of climate change".

In the case of Syncrude Canada Ltd. V. Attorney-General of Canada ${ }^{79}$ which involved the Canadian Environmental Policy Act and Renewable Fuel Regulations, and climate change mitigation and adaptation. The regulations that were challenged by the Syncrude Canada Ltd., were held to be intra vires and "a valid exercise of government authority as part of an overall strategy to reduce greenhouse gas emissions. The Federal Court of Appeal stated: ${ }^{80}$

... there is a real evil and a reasonable apprehension of harm in this case. The evil of global climate change and the apprehension of harm resulting from the enabling of climate change through the combustion of fossil fuels has been widely discussed and debated by leaders on the international stage. Contrary to syncrude's submission, this is a real, measured evil, and the harm has been well documented.

It has been stated that as climate change litigation is gaining speed in Canada:

...the courts should remain alert to the fact that significant scientific consensus on the existence, mechanism and impacts of climate change is already reasonably established. ${ }^{81}$

There has been early attempts by the courts in Canada to enforce climate change action. ${ }^{82}$ There is also the failed private member's Bill known as the Kyoto Protocol Implementation Act (KPIA) aimed at implementing Canada's emissions targets. The KPIA had no government backing though passed into law by the opposition in Parliament, it therefore "had no teeth".

\section{Trends in Climate Change Litigation}

Recent legal decisions as well as court filings emphasises that there are several trends taking place for the purpose of litigations in climate change. The first and foremost trend is holding the government to their policy and legislative related commitments, followed by associating the impacts of extraction of resources to the changes in climate as well as elasticity. The third trend is developing a notion that specific emissions are the immediate reason of any specific adverse effect. This trend is followed by developing legal responsibility for failures to become accustomed to changes in climate and finally, application of the doctrine of the public trust to the climatic changes. ${ }^{83}$ There are several ways in which climate litigation is addressed but the most common ones are applicants seeking compensation against the damage caused due to the climate. ${ }^{84}$ Second, there are instances in which the applicants ask for implementation and development of inclusive recovery plans regarding the climate so that they are able to achieve science-based and more ambitious targets to mitigate issues related to

\footnotetext{
Such Acts of parliament include; The Department of the Environment Act 1971; Weather Modification Information Act 1985; Canadian Environmental Protection Act, (CEPA) 1999; Antartic Environmental Protection Act (AEPA); Arctic Waters Pollution Act; Federal Sustainable Development Act; and other significant legislations on the environment.

76 Voters Taking Action on Climate Change v. British Columbia (Energy and Mines) 2015 BCSC 471 (CanLII); Syncrude Canada Ltd. V. Attorney-General of Canada (2014) FC 776 - (CanLII).

77 (2015) BCSC 471 (CanLII).

78 TQL is a subsidiary of Lafarge Canada Inc.

79 (2014) FC 776, CanL II. (Federal Court of Appeal 2016).

$80 \quad$ Ibid, paragraph 83.

81 Judicial Notice of Climate Change paper, page 1.

82 Friends of the Earth v.The Minister of the Environment (Canada) (2007);Friends of the Earth v.The Governor in Council [2008] FC 1183; [2009] 3 F.C.R. 201.

83 UN Environment Programme, 'The Status Of Climate Change: A Global Review' (2017), 1-41.

84 Keely Boom, et al, 'Climate Justice: The International Momentum Towards Climate Litigation' (2016), 1-72.
} 
the climate. ${ }^{85}$ This also includes effective execution of existing laws. Third, it includes cases in which the applicants seek sanctions for immigration to respond regarding their displacement because of climatic impacts. In the US, the claimant sought after compensation based on the traditional system of tort law, such as asbestos and tobacco litigations. ${ }^{86}$ In order to protect the environment and the people from the climate change, the following are the key trends of climate change litigation.

\subsection{Increase in the Number of Cases Related to the Climate Change}

Combating climate change, its policies and law in the courts has become more as a viable strategy. ${ }^{87}$ The world data regarding climate change litigation includes more than 250 lawsuits, excluding the US across 25 jurisdictions. The US itself includes above 600 lawsuits. ${ }^{88}$ However, majority of the cases are not core to the issue of climate change but is rather looked as a periphery of the matter. For instance, the issues related to projects that deals with fossil fuels are brought in the court since several years but it is only few years that the changes in climate has been used as part of the dispute. ${ }^{89}$

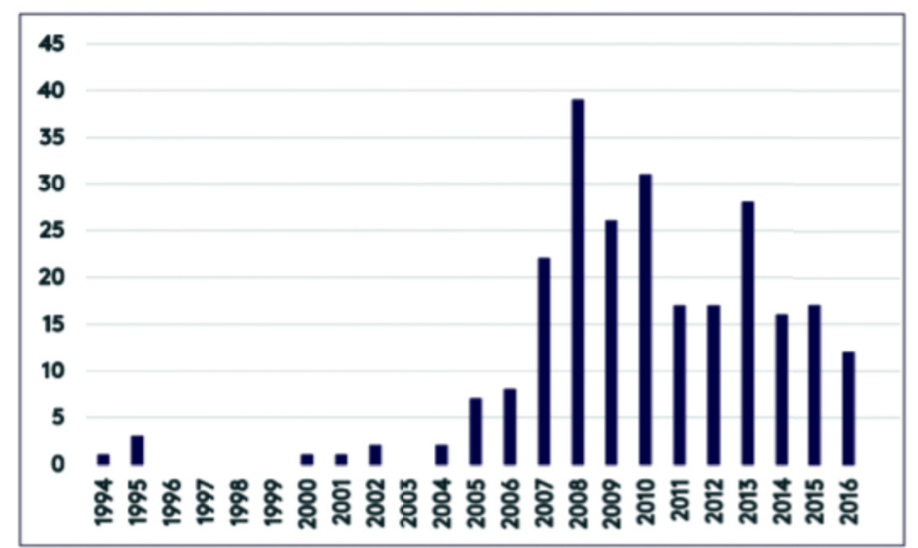

Figure 3. Number of cases for climate change litigation ${ }^{90}$

The above figure 3 depicts the number of litigation cases, from which it is evident that 2008 had the highest number of cases registered in the court.

\subsection{Cases Related to Climate Change Have Several Objectives}

Majority of the cases are registered due to administrative purposes in which the plaintiffs challenge a particular activity or project by filing case. ${ }^{91}$ This is followed by retrieving information and revelation of certain facts, while in such cases the plaintiffs seek court's assistance to gain information from emitting sources or from the government. ${ }^{92}$ Such cases often include claims regarding incomplete or misleading information. Besides, other objectives are related to legislation or policies related matters along with seeking protection against damage and loss incurred. ${ }^{93}$

\subsection{Initiatives Taken by the Corporations}

Most of the companies in recent years are filing cases against the government, aiming to overturn the decisions of the administrative agencies to limit the grant of the licence. ${ }^{94}$ This is done on the basis of the changes that are being taken on the climate caused due to plants and other related activities. ${ }^{95}$ Thus, it can be inferred that

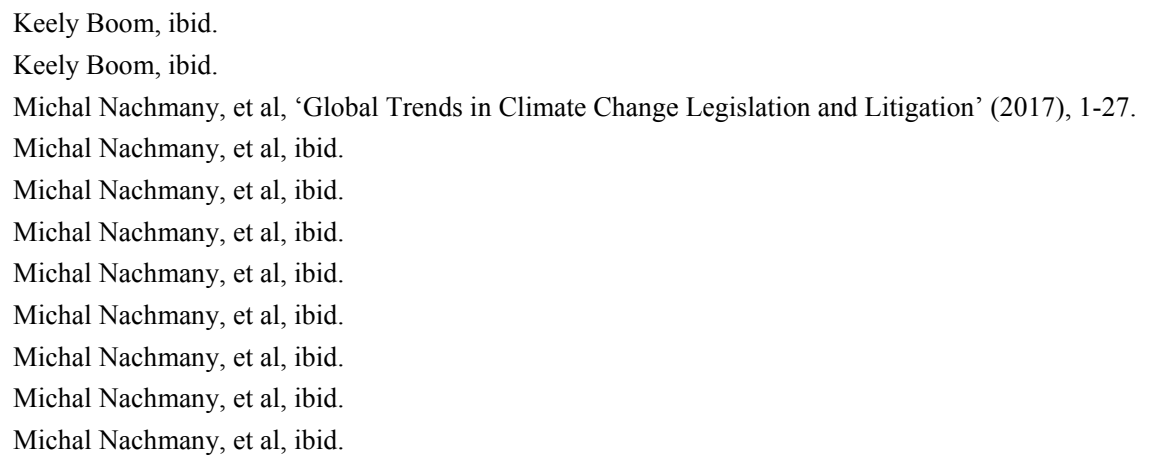


the government have been one of the most common defendants concerning particular regulations or challenging projects. ${ }^{96}$

\subsection{Most of the Court Rulings Preserve or Strengthen Current Climate Regulations}

Litigation can be used to smoothen the progress of climate regulation by clarifying, enforcing and driving the climate legislations and policies. ${ }^{97}$ On the other hand, it can also be used to weaken or oppose the climate regulations. ${ }^{98}$

\section{Fossil Fuel Industry and Climate Change Litigation}

The fossil fuel industry holds for majority of the change in the climate, although a very few steps have been taken to account the issue, while the governments are also alleged to directly be complicit in the maintenance of the exploitation of fossil fuels. ${ }^{99}$ There have been several ongoing efforts to remove the fossil fuel industry from the negotiations related to the climate. ${ }^{100}$ However, these fossil fuel corporations exert pressure on the government for climate litigations, which is particularly prominent when the government takes several legal actions against these industries. ${ }^{101}$ Recently, the major fossil fuel companies, such as American Petroleum Institute (API), American Fuel \&amp; Petrochemical Manufacturers (AFPM) and National Association of Manufacturers (NAM) are intending to escape from the climate lawsuit prior to the trial. ${ }^{102} ;{ }^{103}$ For instance, the API intends to do such because they are well aware of the fact that such trial would expose them and hold them liable for the harms caused to the overall climate system. ${ }^{104}$ However, these organizations in 2015 had claimed that this case was a threat to their respective businesses as a whole, which could even impair their business continuity. ${ }^{105}$ This case further revealed one of the most important aspects that these fossil fuel organizations lacked, such as the relatedness of the change in climate and human activities. ${ }^{106}$

\section{Need for Climate Change Litigation}

In recent years, the rate of climate change has deliberately increased, which is predicted to continue further. ${ }^{107}$ The environmentalists, to a large extent, are filing legal suits for mitigating the issues of climate change but the industries and other agencies are opposing this effort for promoting their interests. ${ }^{108}$ Undoubtedly, the climate change litigation is one of the most important steps taken by the claimants against the defendants for mitigating climate change issues but there are other alternatives that the government in particular can implement and explore. ${ }^{109}$ The governmental bodies are hence directly required to address the problems associated with the major industry that holds accounts for change in the climate. ${ }^{110}$ This is principally because, if the government is unable to address the liabilities, the climate change costs are likely to be carried by the citizens. ${ }^{111}$ Furthermore, if such climate change litigation is not addressed then it might lead to heavy consequences. ${ }^{112}$ Thus, it is important for the government as well as other individuals to take into account the climate change litigations, which would essentially target the major industries that damage the environment. ${ }^{113}$

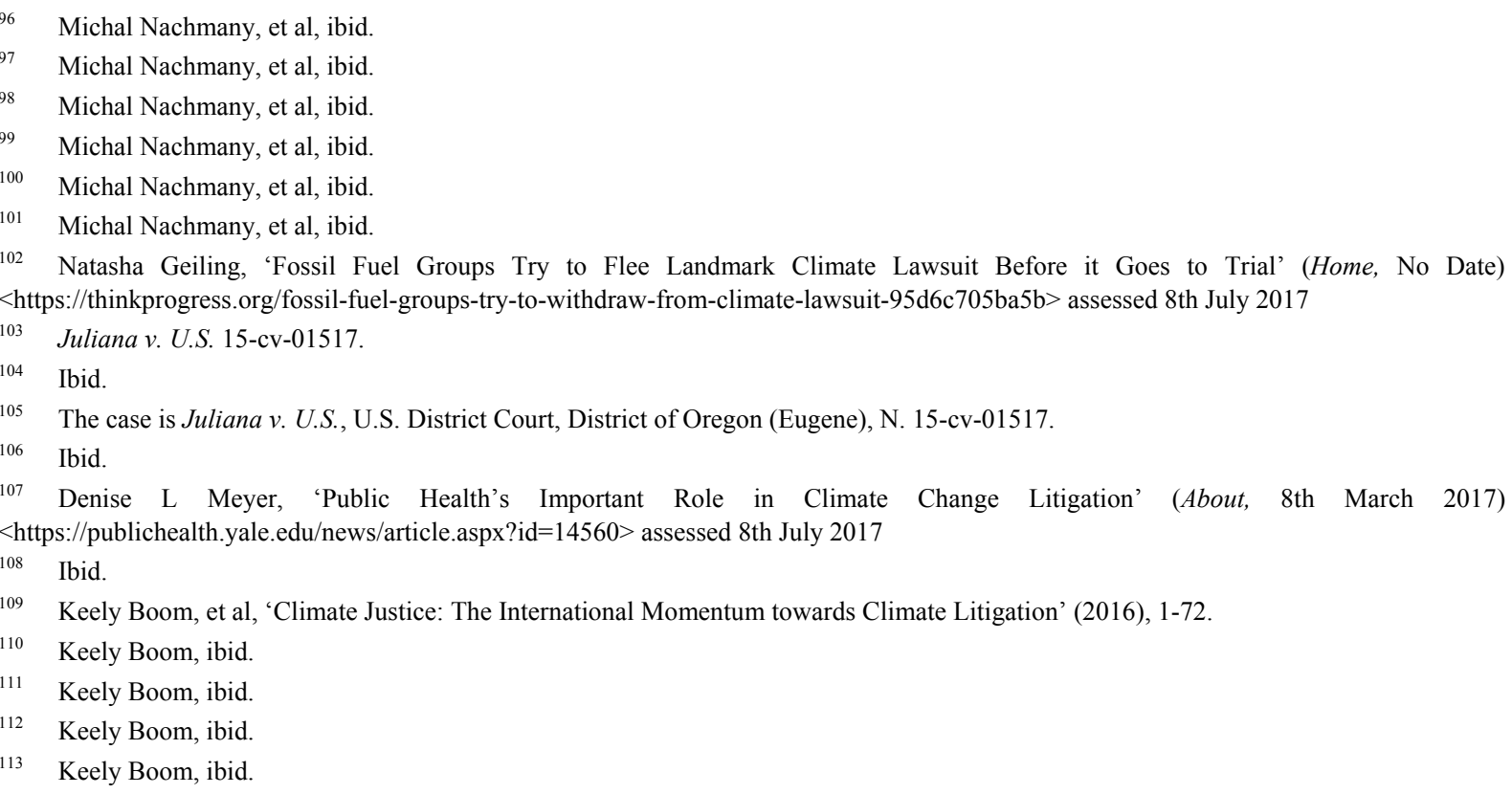


Climate change litigation transcends national, regional and international borders. In New Zealand, the first "climate refugee" case to be determined involved a family of eight who had to flee their country as a result of flood and drought disasters. A family from Kiribati applied for environmental asylum in New Zealand, and Iaone Teitiota and his family applied for refugee status stating climate impacts on their island country in the pacific as a ground. ${ }^{114}$ In the Netherlands case of Urgenda Foundation v. The State of the Netherlands,${ }^{115}$ the Hague District Court issued a landmark judgment in the climate case brought before it by the foundation and 900 citizens against the Dutch Government. Urgenda won the litigation against the Dutch Government. The court held that the Dutch Government is obligated to ensure reduction of its emission by at least twenty-five per cent by the end of 2020 compared to 1990 levels. This case forced the Dutch Government to adopt effective action on climate change. The court relied on the Dutch constitution, the European Convention on Human Rights and the "no harm" principle of international law as a legal basis to protect the citizens against climate change. ${ }^{116}$

The international era of climate change was manifested in the case where the Federated/ states of Micronesia demanded that the Czech Republic discontinue the building of a coal-fired power station, citing the effect of carbon emissions on its natural environment. The court found in favour of the Federated States of Micronesia, though "the polluting activity was not stopped". In 2011 the Republic of Palau requested the International Court of Justice to issue legal opinion on climate change. Palau would want the ICJ to pronounce that countries are under responsibility "to ensure that their emissions do not have a negative impact on other states..."117

This article argues that developing nations are not pro-climate litigation as their developed counterparts. Apart from the few that has constitutional provisions on the environment, ${ }^{118}$ very few of them has cases decided on climate change litigation. ${ }^{119}$ In future this article hopes that the courts would become a veritable instrument to push forward the cause of climate adaptation and mitigation. Litigants who are able to link a particular disaster with climate change impacts are likely to succeed in their climate lawsuits. Though this is not likely to be an easy task, it is expected and would definitely open the doors to climate change litigation. This article therefore, argues that citizens should use the courts to force climate change adaptation actions. This has a great hope for the future because it is the bounden duty of governments to protect their citizens' entitlements to basic human rights which includes environmental rights to a clean and safe environment.

\section{Conclusion}

At present, climate change is increasing rapidly, caused due to several man-activities. Since long, the coal and fossil fuel generating industries are contributing a large amount in deterioration of the climate as a whole. However, there have been minimal efforts to reduce the effects of such activities on the climate. As a result, in recent years, the developed countries, such as the US, the UK and other nations are opting for climate change litigation, as one of the most promising ways to mitigate and protect the environment and the people from the climate change, which are caused due to the activities of the organizations. The adoption of climate change litigation is also widely used in the US, followed by the UK and other developing nations. There are several lawsuits filed by the applicants against the defendants, claiming that the emissions are leading to such change in the climate. In such cases, majority of the defendants are the government, industry actors and other bodies that harm the environment as a whole. Recent trends indicate that the claimants have realized the importance of protecting the environment and the local inhabitants, for which the number of cases regarding the climate change litigations have increased substantially. Trends also indicate that the claimants have several objectives behind for involving into such process of litigation, which particularly varies from person to person.

Conclusively, it can be asserted that protecting the environment and people through climate change litigation is important because the increasing amount of environmental harm is expected to continue hence for which legal actions against the defendants are essential. It is thus observed that the fossil fuel industries are majorly harming

\footnotetext{
114 Andre Leslie, 'Kiribiti Asylum Case Highlights Legal Void on 'Climate Refugees' (2013) in Climate Change, New Zealand, Environment http://p.dw.com/p/IA551.

115 (June 2015) Case number/Cause list number: C/09/456689/HAZA 13 - 1396. Urgenda is a contraction of "urgent agenda".

116 In Austria, citizens overturned the approval for a third runway at Vienna's major airport and in Pakistan, a court decided in favour of a farmer who sued the government over the government's "delay and lethargy" in carrying out its climate change adaptation policies. A Peruvian case that sought redress from a German energy company over the climate impacts suffered was dismissed.

117 Keely Boom, 'See You in Court: The Rising Tide of International Climate Litigation' (2011). The Conversation http://thecovnersation.com (accessed July 9, 2017).

118 India, South Africa, Kenya, Ecuador and Nigeria.

119 See, William C. G. Burns, and Hari M, Osofsky, Adjudicating Climate Change: State, National, and International Approaches, (2009). Cambridge University Press. Book Doi: https://doi:org/10.1017/CBO9780511596766.
} 
the environment and the public health, hence for which the climate change litigation has gained more importance. However, despite several lawsuits against the defendants there is still an increase in the rate of climate change, owing to which it is important that both government and the defendants understand the severity of the matter.

\section{References}

Andrus, K. B. (2012). Beyond Aircraft Emissions: The European Court of Justice's Decision May Have Far-Reaching Implications. The Air and Space Lawyer, 4(24), 1-8.

Bach, T., \& Brown, J. (2008). Recent Developments in Australian Climate Change Litigation: Forward Momentum From Down Under. 8, 1-9.

Boom, K. (2011). See You in Court: The Rising Tide of International Climate Litigation. The Conversation Retrieved July 9, 2017, from http://thecovnersation.com

Boom, K. (2017). Climate Justice: International Momentum Towards Litigation (Home, 30th May 2017) $\begin{array}{llll}\text { Retrieved July } & 7, & \text { 2017, } & \text { from }\end{array}$ http://climatejustice.org.au/climate-justice-international-momentum-towards-litigation/

Desmog Canada. (2014). Climate Litigation is Here and it Could Cost Canadian Oil Companies Billion (Home 9th October 2014) Retrieved July 8, 2017, from https://www.desmog.ca/2014/10/09/climate-litigation-here-and-it-could-cost-canadian-oil-companies-billio ns

Geiling, N. (n.d). Fossil Fuel Groups Try to Flee Landmark Climate Lawsuit Before it Goes to Trial. Retrieved Retrieved July 8, 2017, from https://thinkprogress.org/fossil-fuel-groups-try-to-withdraw-from-climate-lawsuit-95d6c705ba5b

Hayes, G. (2013). Negotiating Proximity: Expert Testimony and Collective Memory in the Trials of Environmental Activists in France and the United Kingdom. Law and Policy, 35(3), 208-235.

Hilson, C. (2011). Climate Change Litigation in the UK: An Explanatory Approach (or Bridging Grievance Back In), pp. 1-18.

Hsu, S. L. (2008). A Realistic Evaluation of Climate Change Litigation Through the Lens of a Hypothetical Lawsuit, 701.

Lytton, T. D. (2007). Using Tort Litigation to Enhance Regulatory Policy Making Evaluating Climate-Change Litigation of Lessons from Gun-Industry and Clergy-Sexual-Abuse Lawsuits. 1837.

Merritt, S. (2017). No Ordinary Lawsuit: Juliana v. United States is a Landmark Precedent for Climate Change Legislation (Academic Commentary, 6th January 2017). Retrieved July 7, 2017, from http://www.jurist.org/forum/2017/01/Gabriela-Steier-juliana-v-united-states.php

Meyer, D. L. (2017). Public Health's Important Role in Climate Change Litigation (About, 8th March 2017) Retrieved July 8, 2017, from https://publichealth.yale.edu/news/article.aspx?id=14560

Milman, O. (2017). More People Heading to Court to Spur Action on Climate Change, Study Finds. The Guardian. Retrieved July $\quad 9, \quad 2017$, from https://www.theguardian.com/environment/2017/may/23/climate_change_government_court_cases_study

Nachmany, M. et al. (2017). Global Trends in Climate Change Legislation and Litigation. 1-27.

Osofsky, H. (2009). Adjudicating Climate Change Across Scales. Adjudicating Climate Change: State, National, and International Approaches. pp. $373-385$.

Osofsky, H. M. (2005). The Geography of the Climate Change Litigation; Implications for Transnational Regulatory Governance. 1789.

Peel, J., \& Osofsky, H. M. (2015). Climate Change Litigation (No. 116). Cambridge University Press.

Phys.org. (2017). Climate Change Litigation Growing Rapidly, Says Global Study (Environment, 25 May 2017). Retrieved July 7, 2017, from https://phys.org/news/2017-05-climate-litigation-rapidly-global.html

Preston, B. (2009). Climate Change Litigation. In Judicial Review: Selected Conference Papers. Journal of the Judicial Commission of New South Wales, 45.

Rachel Pepper. (2012). Climate Change Litigation: A Comparison between Current Australian and International Jurisprudence. 1-16.

Risteard de Paor. (2017). Climate Change and Arbitration: Annex Time Before There Won't Be A Next Time. 
Journal of International Dispute Settlement, 8(1), 179-215. https://doi.org/10.1093/jnlids/idw025

Shaftel, H. (2017). Climate change: How do we know? (Facts, 26 June 2017). Retrieved July 7, 2017, from https://climate.nasa.gov/evidence/

The David Suzuki Foundation. (Issues, 2014). What Is Climate Change? Retrieved July 7, 2017, from http://www.davidsuzuki.org/issues/climate-change/science/climate-change-basics/climate-change-101-1/

UN Environment Programme. (2017). The Status Of Climate Change: A Global Review. 1-41.

United Nations Environment Programme. (2017). The Status of Climate Change Litigation - A Global Review. UNON Publishing Services Section, Nairobi, Kenya, pp. 4-41.

United Nations Environment. (2017). New Study Identifies Key Trends In Worldwide Climate Change Litigation (Environmental Governance, 23 May 2017) Retrieved July 8, 2017, from http://www.unep.org/environmentalgovernance/new-study-identifies-key-trends-worldwide-climate-changelitigation

Vanhala, L., \& Hilson, C. (2012). Climate Change Litigation - A Rising Tide? Roundtable on Climate Change Litigation Policy and Mobilisation. London. Retrieved July 8, 2017, from http://cdkn.org

Wilensky, M. (2015). Climate Change in the Courts: An Assessment of Non-U.S. Climate Litigation. 1-52.

William, C. G. B., \& Hari, M. O. (2009). Adjudicating Climate Change: State, National, and International Approaches. Cambridge University Press. https://doi:org/10.1017/CBO9780511596766

\section{Copyrights}

Copyright for this article is retained by the author(s), with first publication rights granted to the journal.

This is an open-access article distributed under the terms and conditions of the Creative Commons Attribution license (http://creativecommons.org/licenses/by/4.0/). 